\title{
ABBED VILHELM SØGER RÅD HOS PAVE CØLESTIN
}

OMKRING DEN ELDSTE DANSKE SELVBIOGRAFI (Vilh., Ep. II 47)

$\mathrm{AF}$

\section{IVAN BoSERUP}

\begin{abstract}
$A^{b}$ bed Vilhelm af Ebelholt, ca. I 1 25-1203, var en af de mest farverige personligheder i Valdermartidens Danmark. Som ung regelbunden augustiner-kannik, canonicus regularis, ved Ste.-Geneviève kirken i Paris synes han at have udvist så stor selvstændighed, at han kom på kant med sin abbed, og pave Alexander III måtte nedsætte en særlig kommission for at få udredt trådene i den vanskelige sag. Vi kender ikke kommissionens konklusioner eller pavens dom, for i vore kilder henvises der kun indirekte til konflikten, men da biskop Absalon, som måske havde lært Vilhelm at kende tidligere, inviterede ham til Danmark for at blive abbed, tog han imod indbydelsen. Vilhelm kom hertil i i 655 , satte skik på klosteret på Eskilsø i Roskilde fjord og overflyttede det sidenhen til Æbelholt i Nordsjælland, hvor naturbetingelserne var gunstigere. Sideløbende med at han styrede sit efterhånden blomstrende kloster, fungerede han i kongens og $\mathrm{i}$ ærkebiskop Absalons diplomati. Vilhelm måtte udstå megen nød og modgang som klosterleder, og han synes ofte at have overvejet at vende hjem igen til Frankrig. Han døde to år efter sin ven og velgører Absalon. Pave Honorius II ophøjede ham til helgen i I 224 .

Vilhelms studietid lå i den periode, der fulgte efter Abélards fornyelse af lærdomslivet i Paris' berømte klosterskoler. Pierre Abélard døde I I 42 i det kloster, han havde grundlagt og kaldt „Le Paraclet" (af græsk parakletos, „beskytteren, trøsteren“, en betegnelse for helligånden), og Vilhelm kaldte sit St. Thomas kloster i Ebelholt for St. Thomas in Paraclito. Men sin skolastiske lærdom har Vilhelm næppe kunnet stille meget op med i datidens Danmark. Saxo Grammaticus var også europæisk
\end{abstract}


dannet, antagelig i Frankrig, men han var digter og historiker, ikke teolog, og der er intet spor af forbindelser mellem dem. En åndsfælle havde Vilhelm snarere $\mathrm{i}$ den 40 år yngre Parisermagister Anders Sunesen, der sidenhen blev dansk kansler og ærkebiskop i Lund, og som i sit store læredigt Hexaëmeron viste sin tilknytning til den dialektisk-logiske teologi, som Abélard havde fremmet. Vilhelm og Anders var sammen på diplomatisk mission til Frankrig og Italien I 1 93-96 i forbindelse med sagen om den danskfødte dronning Ingeborgs skilsmisse fra Philip August af Frankrig.

For at højne sine danske landsmænds dannelse samlede Vilhelm et antal af sine breve i en Brevbog, tænkt som en samling forbilleder til studium og efterligning for enhver, der ønskede at mestre skrivekunsten. Den er overleveret i to „bøger", men skønt vi endnu har Vilhelms forord, synes han ikke selv at have „publiceret“ værket, dvs. højtideligt afleveret det til sine foresatte. Man kan gætte på, at Vilhelms Liber epistolarum „udkom" posthumt, f.eks. i forbindelse med kanoniseringen af ham som helgen. Som bogen er overleveret, bærer den ikke præg af at være afsluttet. En delvis sammenhængende gruppe på 23 breve omhandler emner inden for den kanoniske ret, indkapslet $i$ en fiktiv brevdialog mellem paven og ærkebiskoppen af Paris; lange passager stemmer ordret overens med Petrus Lombardus' (død i i6o) kirkeretlige encyklopædi, Liber sententiarum. Ellers er der ingen umiddelbart synlige grupperingsprincipper i samlingen, som vi kender den idag. Ialt er ca. I oo breve bevaret. Flere af dem er kun formularer, uden konkret indhold, men mange er udkast til eller afskrifter af officielle skrivelser eller aktstykker. En lang række gennemgående sproglige og stilistiske træk bekræfter Vilhelms ord i forordet om, at samlingen består af ,breve, som jeg dels selv har sendt til forskellige modtagere, dels har forfattet $\mathrm{i}$ andres navn" (epistolas uidelicet, quas ad personas diuersas emisimus uel sub aliorum nomine scripsimus). Brevbogen skulle vise og fremme dygtighed $\mathrm{i}$ at tilpasse sin stil til forskellige situationer. Den lille gruppe såkaldte Ingeborg-breve skal man derfor ikke lade sig friste til at betragte som skrevet af dronningen selv, skønt de her og der dygtigt udmaler hendes harme og angst (Damsholt 1985 og 1986; Alenius I986; for disse og følgende henvisninger se litteraturlisten til sidst).

Kun få af Vilhelms breve rummer selvbiografisk stof $\mathrm{i}$ nævneværdigt omfang. Et enkelt brev, II 47, som skal behandles her, udgør dog en undtagelse. Men skæbnen har villet at der i de sidste 400 år har hersket stor usikkerhed om netop dette vigtige brevs overlevering og agthed. I alle tre trykte udgaver af Vilhelms breve er det således udgivet som to 
brudstykker af to forskellige breve. Denne fragmentariske præsentation har naturligvis indvirket på fortolkningen og forståelsen af brevets indhold. Nedenstående udredning for overleveringen og bevisførelse for, at der kun er tale om ét brev, er afgørende for fortolkningen af brevet og udgør forudsætningen for, at enkelte vigtige punkter i Vilhelms biografi omsider kan falde på plads.

\section{Overleveringen af Vilhelms Brevbog}

Overleveringen af Vilhelms brevsamling beror på et enkelt middelalderligt håndskrift fra begyndelsen af det $\mathrm{I}_{3}$. århundrede. Det befandt sig $\mathrm{i}$ Universitetsbiblioteket, i skabet benæunt Capsa Cypriani, 3. hylde (ordo), hvor det havde nr. 67 , men brændte sammen med resten af bibliotekets indhold i $\mathrm{i} 728$. Inden da havde adskillige lærde dog haft fat $\mathrm{i}$ håndskriftet. $\mathrm{Vi}$ véd f.eks., at Thomas Bartholin genkendte filologen

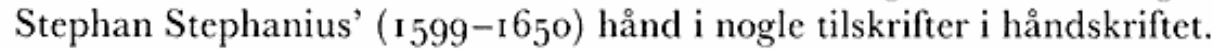

$\mathrm{Vi}$ har bevaret en halv snes håndskrifter, der repræsenterer 5 mere eller mindre fuldstændige afskrifter af den gamle codex i Capsa Cypriani. De findes på Det Kongelige Bibliotek, undtagen ét, der findes i Den arnamagnæanske Samling på Københavns Universitet. De to tidligste afskrifter (betegnet $a$ og $b$ i den sidste udgave, Christensen \& al. 1977) står i forbindelse med historikeren Anders Sørensen Vedel $\left(\mathrm{I}_{54} 4_{2}-\mathrm{I} 6 \mathrm{I} 6\right)$. Den tredie og fjerde afskrift blev udfærdiget for eller af antikvaren Thomas Bartholin ( $1659^{-1690)}$ : af Bartholins ,udgave" af Vilhelmbrevene, i det berømte, men i I 728 ligeledes brændte bind I (A) af hans Collectanea, findes en afskrift $(c 1+c 2)$; håndskriftet $\ell$ synes at være et kasseret tilløb til denne gode afskrift i Collectanea A. Den femte og sidste afskrift, vi har bevaret, $d$, er udfærdiget af en iøvrigt ret ukendt magister Jørgen Claussen (Warbjerg) og er fra tiden kort før branden i i 728 (Christensen \& al. 1977 , s. 420 ).

Men endnu før Vedel arbejdede med det dengang ca. $35^{\circ}$ år gamle håndskrift, var det gået mere eller mindre i opløsning. Hvis håndskriftet stammede fra Æbelholt kloster, kan det været kommet i kongens eje efter reformationen, indtil en nøjere granskning viste, at det rummede materiale af mulig interesse for de kongelige historiografer, og det derpå fra disse kom til Universitetsbiblioteket. Alle vore afskrifter afspejler forskellige skriveres og lærde forskeres reaktioner på den meget defekte codex, de havde foran sig: flere læg og blade havde revet sig løs af indbindingen og var gået tabt eller lagt på plads igen på et forkert sted $\mathrm{i}$ håndskriftet. 
Endnu i middelalderen var håndskriftet blevet forsynet med et Index (indholdsfortegnelse), men dette Index havde aldrig været fejlfrit, og successive velmente forsøg på at få brevstof og Index til at harmonere havde forårsaget nye fejl og modsætninger. Fejlene i Index'et, de store teksttab og de fejlanbragte blade gjorde det alt $\mathrm{i}$ alt umuligt for en afskriver at få hold på samlingen. Det grelleste eksempel på, at den uorden, der opstod antagelig i løbet af 1500 -tallet, har holdt ved, har vi i de trykte udgavers usikkerhed om en eventuel "tredie bog" (Boserup I982).

Et andet eksempel er det mishandlede og misforståede brev II 47 , hvis latinske tekst gengives s.25-26. Brevet bringes her i dansk oversættelse, med de for forståelsen nødvendige reale og kritiske noter, derefter drøftes overleveringen og fortolkningen.

\section{47: Oversattelse:}

Til paven')

Jeg hedder Vilhelm. Jeg var først verdslig og dernæst regelbunden kannik ved Ste.-Geneviève. ${ }^{2}$ ) Jeg blev sendt til Danmark, ${ }^{3}$ ) hvor jeg blev abbed. ${ }^{4}$ ) Erkebiskoppen af Lund ${ }^{5}$ ) har to gange skikket mig til Dem. Den ene gang i Venedig, anden gang i Tusculum. ${ }^{6}$ )

Jeg er nevø af abbed Hugo af St.-Germain, ${ }^{7}$ ) hvem De nærede stor kærlighed til. ${ }^{8}$ ) Han indkvarterede ${ }^{9}$ ) Dem og biskop Bernhard af Porto $^{10}$ ) $\mathrm{i}$ et af Ste-.Genevièves huse nær ved Senlis, ${ }^{11}$ ) dengang I havde været $\mathrm{i}$ Compiègne ${ }^{12}$ ) for at møde hertugen af Magdeburg. ${ }^{13}$ ) Da De altid har næret stor kærlighed til mig for min herre Hugo's skyld, førnæunte abbed af St.-Germain, beder jeg Dem om et råd angående følgende sag.

Jeg var ${ }_{1} 5$ eller 16 år gammel. ${ }^{14}$ ) To medbrødre stræbte efter at komme i besiddelse af mit embede. Da de opdagede at jeg nærede ønske om at hellige mig klosterlivet, prøvede de at narre mig med løgn og list. ${ }^{15}$ ) De påstod, at de stræbte efter samme mål. Vi afgav derfor løfte på evangeliet. Vi traf aftale om et kloster, nemlig Pontigny, ${ }^{16}$ ) og dagen blev fastsat,${ }^{17}$ ) hvor vi så stod foran abbeden, jeg og den ene af dem, men han ville alligevel ikke indtræde. Vi skulle atter vende tilbage til klosteret efter et år, men det skete ikke. Jeg havde nemlig fået øjnene op for deres nedrighed. Imidlertid var St.-Victors ordensregel ${ }^{18}$ ) blevet indført i vor kirke $\left.{ }^{19}\right)$ og denne indtrådte jeg i og underkastede mig dens bestemmelser. Jeg har været medlem af denne orden i næsten $5^{\circ}$ år. ${ }^{20}$ ) 
$\mathrm{Nu}$ beder jeg Deres hellighed, min Herre, skriftligt at tilkendegive over for Deres søn, i hvilken orden jeg gør bedst $\mathrm{i}$ at forblive. ${ }^{21}$ )

Jeg beder også om at De i Deres brev bekræfter, at jeg er fri til at vende tilbage til min kirke $\mathrm{i}$ Paris, når jeg ønsker det, eftersom jeg beholdt min rang og min plads i koret og ved ethvert kapitelmøde, dengang jeg forlod den.

Endelig beder jeg om at Deres brev må rumme trøsterige ord, således at enhver der ser det og læser det kan indse, at De har næret den reneste kærlighed til mig. Og således at jeg berømmes for de trængsler og kriser jeg udstår.

(1) Colestin III (tidl. kardinal Hyacint), I I05-97, pave fra I19I. - (2) St.-Victor's ordensregel blev indfort ved Ste.-Geneviève $1147-48$. - (3) Sensommeren I165. - (4) For augustinerklostret på Eskilsø, sidenhen flyttet til Kbelholt. - (5) Absalon. - (6) Alexander III (pave I 159-81) opholdt sig med sit følge af kardinaler - hvoriblandt Hyacint - i Venedig fra maj til oktober 1177 , i Tusculum fra august 1177 til februar 1180 og fra juni 1 I 80 til juni I 8 I. Vilhelm omtaler sine tidligere møder med brevmodtageren som var denne allerede dengang pave. Vilhelm traf Colestin som pave i Rom i I 194.(7) Vilhelms onkels identitet er diskuteret i Boserup 1987 , hvor der argumenteres for, at det er Hugo VI (abbed 1 162); Brial og Olrik antager Hugo V; Walberg: Hugo IV. Usikkerheden skyldes, at Vita ved omtalen af Hugo benytter dennes slutstilling (abbed), ikke den stilling han havde, da en given episode i Vilhelms liv fandt sted. - (8) Brevmodtageren, Hyacint/Colestin III var med pave Alexander i Frankrig 1 I6I-64. - (9) Ifølge den overleverede tekst var det Vilhelm selv der tog imod de to kardinaler. Jeg har tidligere forsøgt at sandsynliggøre, at teksten ikke er i orden. Den blideste måde at rette teksten på, består i at lade Hugo vare den, der tog imod Hyacint og Bernhard, dvs. rette suscepi til suscepit (Boserup 1987 , s. 65.). - (10) Biskop af Porto og Sta.-Rufina, død ${ }_{1} 176$.

(11) I Borret ved Senlis, $50 \mathrm{~km}$. NØ for Paris (Brial, s. 457). - (12) Ca. $80 \mathrm{~km}$. NØ for Paris. Mødet mellem Wichmann og pavens udsendinge, kardinalerne Hyacint og Bernhard, fandt sted $\mathrm{I}_{1} 6_{1}-62$, hvor man fra andre kilder véd, at der fortes forhandlinger på højt plan mellem skismaets parter (Brial, s. 457). - (13) Wichmann, arkebiskop af Magdeburg 1152-91, stod på det kejserlige parti og havde støttet valget af Alexanders modpave Victor IV. - (14) Her slutter fragmentet II 48 b; resten af brevet er fragmentet II $47 .-$ (15) Historien om de onde, der forgaves hykler fromhed for at narre den fromme, er også fortalt i Vilhelms helgenbiografi, kap. 2-4 (Gertz, s. 301-5; Olrik, s. 180-86), med mange afvigelser og dramatiseringer. - (16) Pontigny/Pont-sur-Yonne, 8o $\mathrm{km}$. S $\varnothing$ for Paris, var et Cistercienser-kloster, grundlagt 1114 . I Vilhelms helgenbiografi kap. 4 drager de unge kanniker til monasterium monachorum, quod Caritas nuncupatur, dvs. Benediktinerklosteret La Charité SV for Paris (Gertz, s. 303; Olrik, s. 184). Forfatteren til helgenbiografien antages normalt at have holdt sig til mundtlige kilder. - (17) Der er et par mindre tekstproblemer i denne passage. Den er overleveret således: Prouisum est 
monasterium Pontiniacum scilicet statuta dies, qua stetimus ante abbatem, ego et unus ex eis *** se uero reddere noluit. Denne passage bliver grammatisk korrekt, hvis man antager at et er faldet ud efter scilicet: prouisum est monasterium, Pontiniacum scilicet, cet statuta dies, qua ... (Vi traf aftale om et kloster, nemlig Pontigny, og dagen blev fastsat, hvor ...). At der kraves interpunktion for se uero reddere noluit, folger af, at vero som adversativ partikel skal stå på andenpladsen. Hvis man derudover sletter komma'et efter abbatem bliver passagen grammatisk set fuldstandig: . . et statula dies, qua stetimus ante abbatem ego et unus ex eis, se vero reddere nolut (og dagen blev fastsat, hvor vi stod foran abbeden, jeg og den ene af dem, men han ville alligevel ikke indtrade). Meningsmassigt savnes intet; mest sandsynligt er derfor, at angivelsen af lakune $\left(*^{* *}\right)$ i overleveringen blot er en folgevirkning af bortfaldet af $t$ efter scilicet $\mathrm{og}$ - i næste led - af en deraf fremprovokeret vildledende interpunktion efter abbatem - (18) En reformeret, mere asketisk variant af Augustinerordenen. - (19) I 1 47-48. - (20) Denne angivelse, fortolket som 48-49 år, ligger bag den almindelige datering af II 47 til 1196 eller 1197 . Da II 47 imidlertid må dateres til 1 191-93 (Walberg: 1191-94), bruger Vilhelm udtrykket „nasten 50" om hvad der historisk var 43-45 år. - (21) Cistercienserordenen eller Augustinerordenen.

\section{Forskning i nyere lid}

Historikeren Peter Frederik Suhm (1728-98) besørgede i bd. 6 af Scriptores Rerum Danicarum den forste trykte udgave af Vilhelms breve (Suhm 1786). Både Anders Sørensen Vedel og Thomas Bartholin havde planlagt udgaver, men ikke ført dem ud i livet; før Suhm var enkelte af brevene blevet trykt af Thomas Bartholin, Ludvig Holberg ( $168_{4-}$ I754), Erik Pontoppidan (1698-1764) og Hans Gram (1685-1 748) (Bartholin I689, Holberg 1732, Pontoppidan I 741, Gram i 746).

Suhm foreslog tøvende, at det brudstykke af et brev, som han navngav „II $48 \mathrm{~b}$ “, kunne være begyndelsen af det brudstykke, som hos ham hed II 47. Han skrev i en note til II 48b: forte est principium epistola 47 (Måske er dette begyndelsen af brev 47) (Suhm I786, s. 61). Suhms gisning byggede på Thomas Bartholins forsøg på datering af samtlige breve og brevfragmenter, idet begge brudstykker var blevet henført til året I 197 i Bartholins efterladte utrykte hovedværk, en kirkehistorie i årbogsform kaldt Annales ecclesiae Danicae fra ca. I6go (Det Kongelige Bibliotek, E don. var. $\left.12^{\circ}\right)$. Det kan ikke udledes med sikkerhed af Suhms ord, om han mente at de to stykker tilsammen kunne udgøre hele brev II 47 , eller om der efter hans opfattelse manglede et længere stykke mellem de to bevarede fragmenter. Men den franske abbed Michel Jean Joseph Brial, som i 1824 udsendte en samlet undersøgelse af Vilhelmbrevene i bd. 16 af Histoire littéraire de la France, tog for givet, at der var tale om et helt brev, idet han undrede sig over at Suhm havde „skåret 
det midt over" (coupé en deux) og trykt delene i omvendt rækkefølge (Brial, s. 469). I sin Abbed Vilhelms Levnet støttede Anders Damborg sig kraftigt til Brial, og han behandlede også II 48b og II 47 som om de var to dele af ét og samme brev (Damborg I867, s. 14, I8, 2 I, 54, 58, 83). Det samme gjorde Hans Olrik i noterne til sin oversættelse af Vilhelms helgenbiografi i Danske Helgeners Levned (Olrik I894, s. 180, I84, I86.).

I sin oversigtsartikel om Vilhelmbrevene betragtede også filologen William Norvin de to fragmenter som dele af ét og samme brev, II 47 (Norvin I933, s. I6 I f.). Men han fandt, at man havde taget lidt for flot på overleveringens kendsgerninger. I det gamle Index til brevsamlingen var II 47 et brev til paven, og som følge af en passus i slutningen af fragmentet, som daterede det til ,næsten 50 år" efter 1 1 47-48, havde man derfor anset det for at være et brev til Cølestin III, pave II9I-97, og dateret brevet til 1 197. Index'et var imidlertid et sekundært produkt, blot et udtryk for en tidlig læsning af brevene, og fragmentet II $48 \mathrm{~b}$ var overleveret med overskriften Ad dominum Petrum; Suhm havde refereret, at Arne Magnussen ( $1663^{-1} 730$ ) mente, at Pelrum skulle rettes til papam, og det havde alle taget for gode varer. Men nu indtog Norvin det modsatte standpunkt: overskriften til II 47 Ad dominum papam og den tilsvarende Index-indførsel måtte forkastes. Ifølge Norvin var II 47 (II $48 b$ + II 47) ikke skrevet i Danmark, til paven i I 197, men i Frankrig, til en Petrus, der måtte være en fransk gejstlig, i i 196 .

Norvin planlagde en ny udgave af Vilhelmbrevene inden for rammerne af Diplomatarium Danicum. Men han døde i i 940 , og ansvaret for en ny udgave blev overdraget til historikeren Lauritz Weibull. I i 943 udsendte Lauritz Weibull en artikel, hvori han sensationelt påpegede, at Vilhelm i fragmentet II $48 \mathrm{~b}$ henvendte sig til en person, som (1) var pave og (2) havde truffet Vilhelm i Venedig og i Tusculum, hvorfor brevmodtageren af II 48b måtte være Alexander III, pave I I59-8I (Weibull 1943). Der måtte altså være tale om to brudstykker af to forskellige breve, med mindst ro år imellem, for fragmentet II 47 måtte helt sikkert dateres til pave Cølestins III's embedstid I I 9I-97.

Det vigtigste for Weibull som historiker var, at han mente at have opdaget og tidsfæstet et storpolitisk møde i Compiègne i begyndelsen af april måned I $_{1} 6_{5}$ (umiddelbart før Vilhelm tog til Danmark), „som hittills varit okänt för den historiska forskningen". Det store skisma, som indledtes da den tyske kejser i I 159 valgte sin egen "modpave“ i protest mod Alexander III's krav om overhøjhed, var kommet ind i en ny fase efter at Victor IV, kejserens første modpave, var død ${ }_{11} 64$. Abbed Vilhelm omtaler i fragmentet II $48 \mathrm{~b}$ et møde mellem biskop 
Bernhard af Porto, biskop Wichmann af Magdeburg og brevmodtageren. Brial havde dateret mødet til ca. I 162 og var blevet fulgt heri af Anders Damborg og Hans Olrik. Nu foreslog Weibull, at der var tale om et topmode i ir 65 mellem pave Alexander III i egen høje person og ærkebiskop Wichmann, der repræsenterede den tyske kejser Frederik Barbarossa. Mødet skulle ifølge Weibull være kommet i stand på kejserens foranledning: Rigsdagen i Würzburg var indkaldt til d. 27. maj, Wichmann skulle „en sista gång sondera terrängen“, og Alexander, der opholdt sig i Sens lidt syd for Paris, skulle da i stor hast være rejst til Compiègne for at møde Wichmann. En kirkefred kom der dog ikke ud af det topmøde, Weibull „opdagede“. Skismaet ophørte først i i i 77.

Der meldte sig kun én skeptiker. Romanisten Emmanuel Walberg fandt at fragmentet II $48 \mathrm{~b}$ var for lidt underdanigt i tonen til at være et brev til en pave, og han nægtede at tro, at Alexander III havde kunnet rejse så hurtigt frem og tilbage til Compiègne, som Weibulls model forudsatte (Walberg i 944 a). Walberg godtog Weibulls adskillelse af II $48 \mathrm{~b}$ og II 47, og han godtog Weibulls datering af Compiègne-mødet, men med hensyn til brevmodtageren af II $48 \mathrm{~b}$ vendte han tilbage til Norvins position: han foreslog kardinalen Petrus de Bono, der ligesom Bernhard af Porto hørte til inderkredsen omkring Alexander III.

Walberg blev i første omgang et let bytte for Weibulls sarkasmer (Weibull I944), men dennes antikritik gjorde det kun endnu mere klart, at grundlaget for Weibulls konstruktion var meget spinkelt. Walberg kunne derfor endnu samme år svare igen med den indlysende rigtige løsning (Walberg 1944b): det var hverken Alexander III eller en kardinal Petrus, der havde ledsaget biskop Berhard til mødet med Wichmann, men kardinal Hyacint (Giacinto di Bobone, kardinaldiakon af Sta. Maria in Cosmedin), den senere pave Cølestin III. Walberg næunte, at allerede Hans Olrik havde peget på Hyacint, men her fulgte Olrik blot Brial og Damborg. Nu faldt alle brikkerne på plads. Suhm - dvs. i sidste ende Thomas Bartholin - havde altså haft ret i sin forsigtige antagelse: de to fragmenter var dele af ét og samme brev, et brev til pave Cølestin III.

Weibull svarede aldrig Walberg, men denne vendte nogle år senere tilbage med en sammenfatning på fransk af hele diskussionen (Walberg I947).

Hvad kom der alt $\mathrm{i}$ alt ud af Norvins, Weibulls og Walbergs vildfarelser? Et fremskridt var det, at Walberg sluttede, at det restituerede brev II 47 ikke kunne stamme fra Cølestins sidste år, som antaget af alle 
indtil da, men måtte stamme fra hans første paveår, I 191-94, eftersom Vilhelm nævnte sine møder med Hyacint/Cølestin hos pave Alexander i Venedig og i Tusculum, men ikke nævnte sit møde med ham i Rom i foråret I I94. Mærkværdigvis fastholdt Walberg Weibulls omdatering af mødet i Compiègne til april I 165 , skønt grundlaget for at antage et topmøde (med deltagelse af pave Alexander selv) nu var faldet bort.

Her kunne historien om misfortolkningen af II 47 være sluttet, men konklusionerne på den svenske debat nåede aldrig rigtig frem til Danmark. I 1978 skrev Nanna Damsholt i sin afhandling om Vilhelmbrevene „En lille tekst i samlingen, nemlig liber II, $48 \mathrm{~b}$, virker som et stykke af en selvbiografi: Ego sum ille Willelmus etc. Det er dog nok snarere en del af et brev, som det står anfort, men kun dette lille stykke refererer i få ord til Vilhelms tid før ca. I 165" (Damsholt 1978, s. I9, note 57). Hun tog altså ikke stilling til det afgørende spørgsmål, som Suhm havde ladt stå åbent, om forholdet mellem II $48 \mathrm{~b} \mathrm{og} \mathrm{II} 47$. Det gjorde man derimod i den nye udgave af abbed Vilhelms breve, Diplomatarium Danicum I:3, 2. del, afsluttet efter Lauritz Weibulls død af C. A. Christensen og Herluf Nielsen: fragmentet II 47 aftrykkes som II 47 , men fragmentet II $48 \mathrm{~b}$ aftrykkes under overskriften „Additamentum" til allersidst i udgaven, efter fragmenterne af „Tredie bog“ (Christensen \& al. I977, s. 575 f.). I kommentaren henvises til de 4 forste dele af Weibull-Walberg polemikken, men udgiverne har ikke læst Walberg 1944b til ende og har overset Walberg 1947. Udgiverne skriver: „Walberg vil holde fast ved Petrum og identificere ham med en temmelig ubekendt kardinal Petrus De Bono."

Walbergs løsning efterlader en lille tvivl, idet Vilhelm ifølge Walberg i fragmentet II 48b skrev til Cølestin III, at Absalon havde sendt Vilhelm til Venedig og til Tusculum for at møde ham; der må sigtes til forhandlinger med paven, men da møderne blev holdt, hed paven Alexander III, og Hyacint var endnu kun en fremtræedende kardinal ved pavehoffet. Modsætningen forledte Weibull, der tolkede teksten ordret, til at betragte Alexander som brevmodtageren; er Cølestin brevmodtageren, må man altså antage, at Vilhelm med fuldt overlæg smigrer Cølestin ved at udtrykke sig mindre præcist og skildre Cølestin som hovedperson $\mathrm{i}$ forhandlinger, der fandt sted, længe før han faktisk blev pavehoffets centrum. At denne retoriske fortolkning af Vilhelms ord er den rigtige, vil først være hævet over enhver tvivl, hvis det overleveringsmæssigt kan bevises, at de to brevfragmenter udgør ét brev. Det er derfor nødvendigt at se nærmere på fragmenternes overlevering. 


\section{Overleveringen}

Walberg henviste til det generelt uafklarede spørgsmål om håndskrifternes indbyrdes forhold og Index'ets mange fejl, da han ligesom Norvin bestemte sig for Petrum frem for papam som brevmodtager, og igen da han bestemte sig om og ligesom Arne Magnussen og Suhm valgte papam i stedet for Petrum. Der vil naturligvis forblive plads til tvivl, sålænge der ikke kan gives en holdbar forklaring på, hoorledes det kan vare gået til, at et brev Ad dominum papam er blevet rubriceret som et brev Ad dominum Petrum. Det er derfor prisværdigt, at de nye udgivere har anset det for en del af deres opgave at give forklaringer på de fejl, der forekommer i brevoverskrifter og Index-indførsler. Problemet om II 48b's overskrift mener udgiverne skal løses på den måde, at Arne Magnussens rettelse af Petrum til papam fortolkes som en forkert opløsning af forkortelsen $p$, som Petrum i stedet for papam - altså en banal afskriverfejl i en iøvrigt rigtig brevoverskrift (Christensen \& al. 1977, s. 576). Men det er en meget tvivlsom forklaring, om ikke af andre grunde, så fordi den normale forkortelse for $p a p a$ er $p p$.

De nye udgivere mener at kunne underbygge Weibulls adskillelse af de to fragmenter gennem en analyse af overleveringen. I deres Indledning ( 1977 , s. 420) finder vi en vanskelig men detaljeret redegørelse for eksistensen af II $48 \mathrm{~b}$ (udgivernes såkaldte „Additamentum“). Jeg citerer hele afsnittet, som følger umiddelbart efter udgivernes forfejlede redegørelse for ,genvindingen “ af fragmenterne af en postuleret „Tredie bog" (Christensen \& al. 1977, s. 420; mine tilføjelser i klammer):

„Ud over disse fragmenter [af „Tredie bog“] har der været et Additamentum i membranen af en særlig karakter. I SRD. VI [Suhm i 786] 6I er det placeret som II $48 \mathrm{~b}$. Det kendes kun gennem Vedel $(b)$, som i sin indholdsoversigt, Catalogus, over membranen [læs: indholdet af $b$ ] opfører det som nr. I. I Bartholins Annales (bd. 18) noteres under 1197 i tilknytning til referat af II 47: Hic iungi potest initium cuiusdam epistola, licet tribus rubris lineis in ms. delelum. I Gl. kgl. Saml. I I I $5(c l)$ hedder det efter II 48 (!): NB. Insertur hic principium cuiusdam epistole, tribus lineis rubris deletum, adscripto in margine: Vacat. Quod tamen quia ad historiam ipsius Willelmi facit adscripsi. I AM. I054 $4^{\circ}$ [antagelig en for Arne Magnussen udfærdiget afskrift på løsblade af Vilhelmbrevene i Bartholins Collectanea A] findes teksten ligeledes anført på den fejlagtige plads, men uden den hertilhørende notits. Bartholins tanke, at notitsen og II 47 hører sammen, har L. Weibull godtgjort er forkert. II 47 må være skrevet I $196-97$, mens foreliggende udtog må stamme fra et brev fra pave Alex- 
ander III's tid... Efter de anførte oplysninger kan det antages, at brevudtoget i membranen har stået på en løs seddel i tilknytning til prologen. Den, der har tilføjet denne seddel, har tilsyneladende opfattet udtoget som et egnet biografisk supplement til prologen...".

Dette forsøg på at finde en codicologisk bekræftelse på Weibulls teori er ikke holdbart. Man skal altid vare på vagt, når der indføres „løse sedler" i en overlevering for at fă løst et enkelt drilagtigt problem. Udgangspunktet for udgiverne er Vedels afskrift $(b)$. Det er rigtigt, at II $48 \mathrm{~b}$ står forrest i Vedels afskrift og derfor anføres i spidsen af indholdsfortegnelsen, Catalogus, over Vedels afskrift (ikke over membranen!); men at II $48 \mathrm{~b}$ står forrest er ikke ensbetydende med, at det er blevet afskrevet først. Faktisk står det i spidsen (,som nr. I“), fordi det er afskrevet sidst: Vedel begyndte ikke sin afskrift på første side af det første læg, men brugte de første sider som smudsblade. Afskriften af Vilhelmbrevene begynder først på side 5 , med breve fra bog I, efterfulgt af breve fra bog II - alle i samme rækkefølge som i de øvrige afskrifter af den gamle codex. Men til sidst, efter afskriften af fragmentet II 47 på sidste side af sidste læg, var der ikke mere plads på siden, og Vedel måtte da ty til de første sider af første læg, som han til at begynde med havde ladt stå ubeskrevne, og her afskrev han så fragmentet II $48 \mathrm{~b} . \mathrm{Vi}$ kan altså konkludere om II 48b's plads i overleveringen, at såvel Vedel som Bartholin fandt det på samme sted $\mathrm{i}$ håndskriftet, $i$ ret umiddelbar narhed af fragmentet II 47 : Vedel afskrev det lige efter fragmentet II 47 , Bartholin mellem II 48 og II 49.

Vi står nu over for fire spørgsmål: (1) hvordan kan det gå til, at II $48 \mathrm{~b}$, hvis det skal være begyndelsen af II 47 , er afskrevet af Bartholin imellem II 48 og II $49^{\text {? } ~-~(2) ~ h v o r d a n ~ e r ~ b r e v e t ~ I I ~} 47$ blevet til to fragmenter med hver sin overskrift? - (3) hvorfor er overskriften over sidste del (Ad dominum papam) rigtig, men overskriften over første del (Ad dominum Petrum) forkert? - og (4) hvorfor har II 48b været overstreget $\mathrm{i}$ det tabte håndskriftforlæg $\mathrm{i}$ Capsa Cypriani? Sådanne problemer kendes ikke fra de andre breve $\mathbf{i}$ overleveringen, dvs. at de sandsynligvis alle fire er afledt af én og samme overleveringsmæssige begivenhed.

Som det er fremgået har mange forskere forsøgt at finde løsningen, men hidtil har alle betragtet de to fragmenter løsrevet af deres kontekst i brevsamlingen. Sammenholder man II 47 med II 46, 48 og 49, er der imidlertid to bemærkelsesværdige forhold, der springer i øjnene: (1) II 49 har samme overskrift som II 48b: Ad dominum Petrum, idet II 49 med rette er blevet rubriceret som et brev til Peder Sunesen (2) II 46 og II 48 


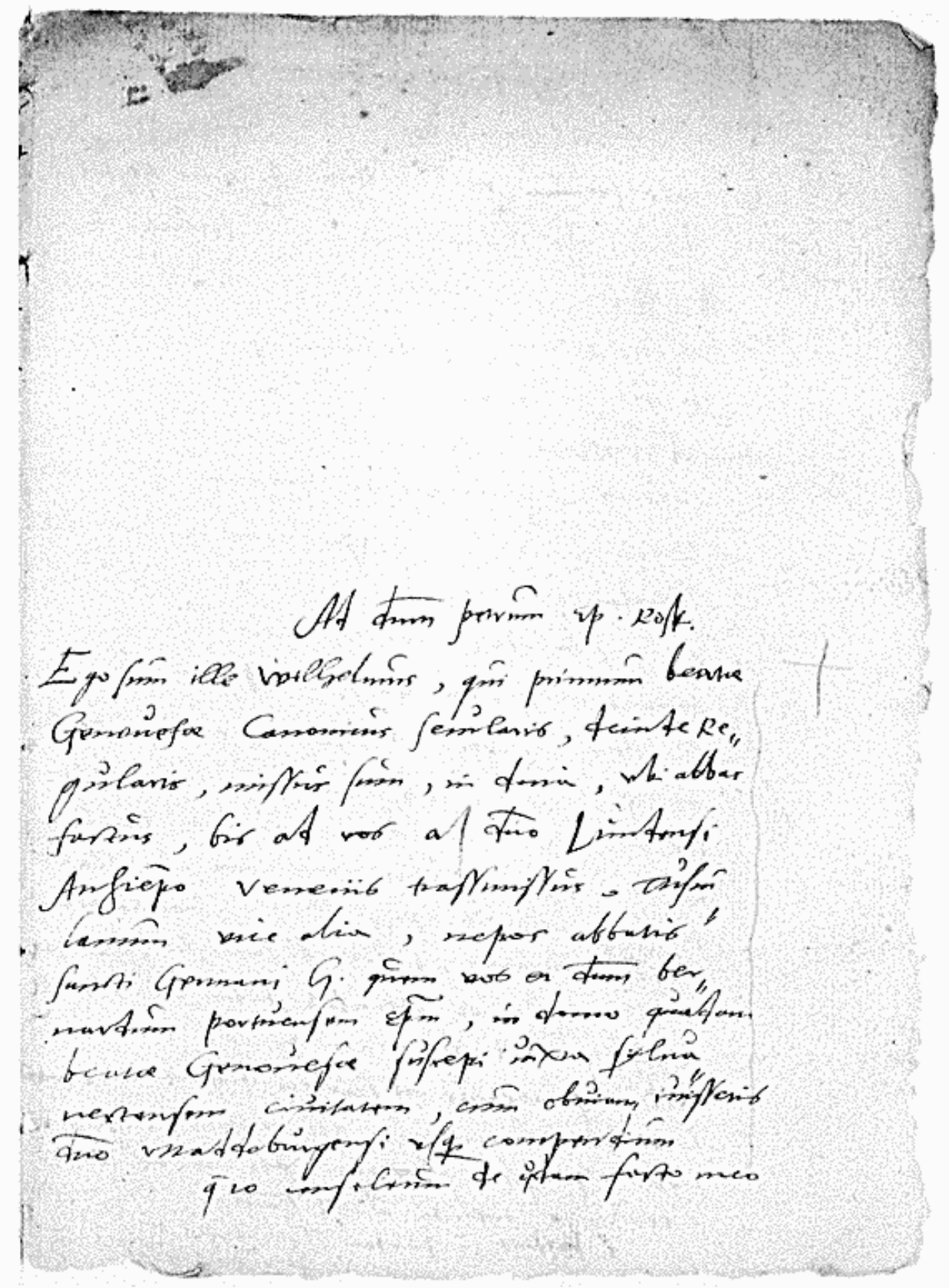

II 47 , I. del („II $\left.48 b^{40}\right)$ i Anders Sørensen Vedels afskrift, NkS 2155 b (1. del) $4^{\circ}$ (b): Ego sum ille Wilhelmus... 


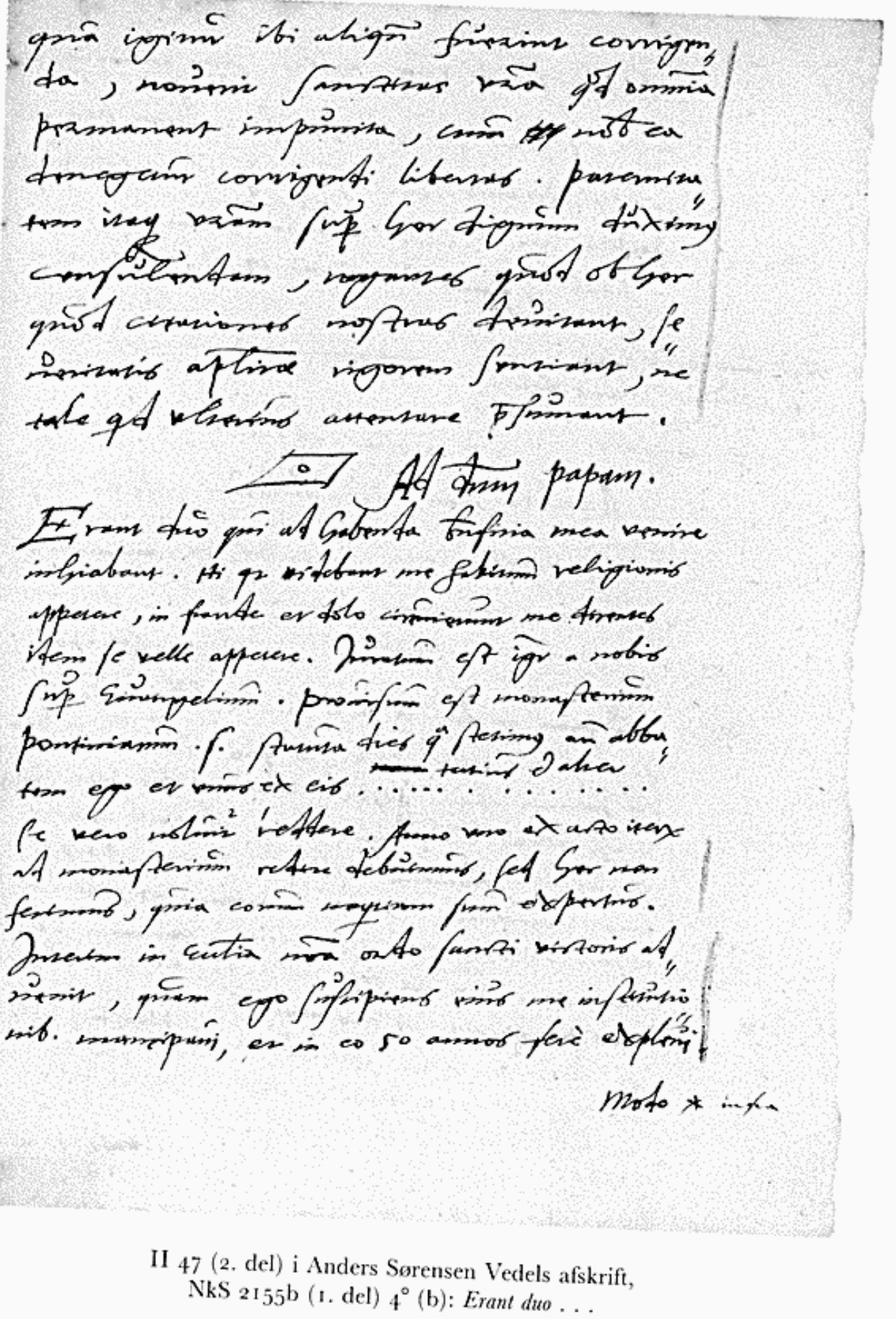


handler om det samme, dvs. de kunne ved en overfladisk betragtning blive forvekslet. Løsningen skal findes i denne overfladiske lighed mellem brevgrupperne II 46-47 og II 48-49. Nedenfor gengives Indexindførsler og overskrifter for brevene II 46-49, før afskrivere og lærde begyndte at ræsonnere over og gribe ind i overleveringen:

Nr. Index-indførsel

Overskrift

46 Abbed Vilhelm til paven, med en klage over, at grå munke er blevet pryglet af sorte munke.

47 Som forrige til paven, med krav om svar om hvilken orden han gør bedst $\mathrm{i}$ at forblive $\mathrm{i}$.

Ad dominum papam.

8 Som forrige, imod de sorte munke.

49 Som forrige, til Roskildebispen, et bønskrift for en slægtning.

Ad dominum Petrum.

Ad dominum papam.

Ad dominum Petrum.

Det håndskrift-historiske forløb må have været omtrent som følger. Oprindelig havde II 47 ikke nogen overskrift. Der er stadig en rakke breve, som aldrig har fået en overskrift, i flere tilfælde fordi overskriften blot ville have gentaget hvad der stod $\mathrm{i}$ brevets første linie, således I 39, II I I (b), II 55. I Index blev II 47 indført helt korrekt som et brev, hvori Vilhelm beder paven om et råd: Item ad eundem, in qua postulatur, in quo sit ei ordine securius permanendum (oversat ovenfor). Den helt usædvanlige konstruktion postulare + indirekte sporgsmål skyldes hastværk under redigering af Index, idet brevet rummer dels en bøn til paven, dels et spørgsmål. Den, der sidenhen tilføjede overskriften, for at gøre det lettere at finde fra Index til brev (numre synes først at være kommet til senere endnu), burde altså have skrevet $A d$ dominum papam. Men på grund af ligheden i Index mellem II 46 og II 48 forvekslede han II 47 med II 49. II 49, der er et brev til Roskildebispen Peder Sunesen, anføres i Index med følgende ord: Item ad episcopum Roskildensem intercessoria pro quodam familiari (oversat ovenfor). Denne indførsel om II $49 \mathrm{er}$ altså ,kilden“ til II 47's overskrift Ad dominum Petrum: II 47 fik i Capsa Cypriani-håndskriftet en overskrift, som hørte til II 49.

Det næste der skete var, at en læser undrede sig over at II 47 , som henimod slutningen helt evident var et brev til en pave, var rubriceret som et brev til Roskildebispen hr. Peder Sunesen. Denne læser konfererede så med Index og konstaterede, at II 47 var et brev til en pave, hvorfor han stregede begyndelsen af brevet ud (med tre røde streger, tribus lineis rubris) og tilføjede en ny overskrift til sidste del af II 47 : $A d$ 
dominum papam. Det er standardoverskriften for brevene til en pave, jfr. f.eks. II ${ }_{4} 6 \mathrm{og}$ II 48 . Senere benyttere af håndskriftet mødte altså et overstreget fragment Ad dominum Petrum, hvortil intet svarede i Index, og slutningen af et brev Ad dominum papam, som svarede smukt til en indførsel i Index.

Dette var situationen, da de bevarede afskrifter blev til, dvs. fra og med slutningen af ${ }_{15}$ oo-tallet. Kun 4 af de 5 kendte afskrifter nåce til brev II 47. To af dem $(a \circ g e)$ rummer intet spor af det overstregede brudstykke II $48 \mathrm{~b}$, fordi skriverne, der var betalt for at afskrive og ikke for at tænke, fulgte de meget tydelige signaler, som hăndskriftet selv gav. Men de to andre afskrifter ( $b$ og det brændte forlæg for $c l+c 2)$, der skyldtes henholdsvis historikeren Vedel og antikvaren Thomas Bartholin, blev afskrevet til disses eget brug og afspejler derfor et helt anderledes selvstændigt og kritisk forhold til håndskriftets udsagn om sit eget indhold. Med henblik på sin planlagte Danmarkshistorie afskrev Vedel overhovedet kun breve med et egentligt historisk indhold: Ingeborgbreve $o g$ breve, der handlede om Vilhelms liv. Da fragmentet II $48 \mathrm{~b}$ handlede mere om Vilhelms liv end noget andet brev, måtte han have det med, trods håndskiftets fordømmelse af det. Bartholin gjorde sig anstrengelser for at harmonisere breve og Index, og han afskrev derfor hver Index-indførsel sammen med det tilhørende brev. Fragmentet II $48 \mathrm{~b}$, som ikke havde nogen indførsel i Index, lod han derfor hange i luften, indtil han nåede til det ,,andet" brev til Peder Sunesen, II 49. Her indføjede han det (Insertur hic principium cujusdam epistola), trods udstregningen (licet tribus lineis rubris in ms. deletum), på grund af dets historiske indhold (quia ad historiam ipsius Willelmi facil). Hos Vedel $(b)$ har den forkerte overskrift fået ekstra troværdighed gennem en lærd udvidelse: Ad dominum Petrum episcopum Roskildensem. Bartholin har bevaret håndskriftets form: Ad dominum Petrum.

Således analyseret bekræfter overleveringen, at Weibull tog fejl. Resultatet kan forekomme magert, al den stund Walberg for over 40 år siden har modbevist Weibull, men vi kan dog notere et lille fremskridt i forhold til det punkt, Walberg havde ført diskussionen frem til: først nu, hvor overleveringen af II 47 er klarlagt, kan vi med sikkerhed sige, at der ikke mangler noget mellem fragmenterne II $48 \mathrm{~b}$ og II 47 : intet i overleveringen peger på et brud eller en lakune. Vi kan derfor for første gang udgive abbed Vilhelms brev II 47 i sin helhed og læse det i sammenhæng (se Appendix), samt drøfte nogle historiske og litterære spørgsmål, som brevet rejser, i et nyt lys. 


\section{Intern kronologi og litterer kvalitet}

Fra andre kilder ved vi, at Vilhelm kunne være meget præcis i sine angivelser af årstal. Kort efter Absalons død (april r201) skrev han, at det var 38 år siden han kom til Danmark. Men i II 47 er han påfaldende vag, og hans regnestykke synes ikke at ville gå helt op.

Vilhelms fødsel kan med nogenlunde sikkerhed sættes til I I 25-27. Han var altså 20-23 år gammel i I $_{147}-48$, da St.-Victor's ordensregel blev indført ved Ste.-Geneviève kirken. Som Vilhelm skildrer hændelsen med det brudte klosterløfte til Cistercienserne i Pontigny, făr man imidlertid et helt andet indtryk af hans alder: han var endnu et barn (puer)

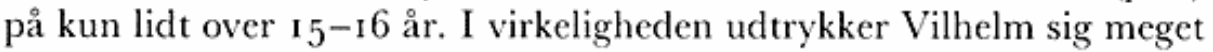
uldent og tvetydigt. Går man hans tekst lidt nøjere efter, siger han ikke hvor gammel han var, da han var i Pontigny. Det eneste han siger er, at han var ${ }_{15-16}$, da hans fjender begyndte at lægge anslag imod ham. Den kronologiske sammenknytning mellem Pontigny og 1 147-48 er lige så vag: ordet interim, som forbinder de to episoder, betegner normalt en samtidighed, men kan udmærket betegne et ret langt tidsinterval.

II 47 kan med stor sikkerhed dateres til II9I-93. Vilhelm var da 66-68 år gammel. Han skriver at han har varet medlem af St.-Victor's orden i ,næsten 50 år", men strengt taget er der kun tale om 43-45 år. I I 47-48 er imidlertid ikke et årstal Vilhelm selv angiver, tværtimod daterer han sin indtræden i St.-Victor's orden ud fra Pontigny-affæren, dvs. sin egen $16-18$ års alder ( $15-16$ plus lidt til). Regnet fra tidspunktet for Pontigny-affærens begyndelse - Vilhelms forste kontakt med de kirkelige ordener - er opgørelsen ,næsten 50 år" altså ikke så upræcis endda.

Den kronologi Vilhelm opererer med i II 47 er ikke den samme som vores. Han går ikke ud fra det, som tilfældigvis er vores eneste præcise og faste holdepunkt: 1 1 47-48. Han går ud fra sin egen alder: 66-68 år, fratrækker et halvt sekel (næsten $5^{\circ}$ år) og definerer den resterende del (16-I8 år) som perioden indtil han blev regelbunden kannik.

Hvad Vilhelm opnår litterært og psykologisk ved hjælp af denne fremstilling af det tidsmæssige forløb må ses på baggrund af det erklærede formål med hele brevet. Vilhelm vil have Cølestin til at udstede et dokument som bekræfter at han fortsat har „orlov" fra Ste.-Geneviève kirken og kan vende tilbage til sin tidligere plads og rang når han vil. Dette formål er styrende for Vilhelms skriveproces i brevet, fra første til sidste sætning. Det gælder såvel udvalget af begivenheder som den stilistiske udformning. Med hensyn til den i netop denne sammenhæng 
særdeles vigtige begivenhed: Vilhelms indtræden i St.-Victor's orden, iværksætter han en fortætning i beretningen: hændelser som indtraf spredt og uden indbyrdes sammenhæng over en periode på måske 5 år, fra hans 15 . til hans 20.-23. år, skildres, som var de tæt forbundne-i tid og som årsag-virkning. Gennem dette stilistiske greb opnår han, uden at have skrevet noget som helst som er i direkte modstrid med sandheden, at skabe tre tydelige forestillinger hos læseren (Cølestin), som støtter brevets overordnede formål:

I) Det brudte løfte til Cistercienserne i Pontigny hørte til Vilhelms meget tidlige ungdom;

2) Straks efter denne vildfarelse blev han regelbunden kannik (Augustiner ordenen);

3) Lige siden, i snart et halvt århundrede, har han været trofast medlem af denne orden.

Endelig skal der erindres om, at Vilhelm indledningsvis smigrer Cølestin ved at betone hans betydning ved pavehoffet, længe før han blev valgt til pave.

Betragtet i sin genvundne helhed er brev II 47 - Danmarks første selvbiografi - ikke blot en betydningsfuld kilde til abbed Vilhelms liv. Det er også et dokument, som måske klarere end andre af hans breve viser os Vilhelms kompositionsteknik og skrivekunst på sit højeste.

\section{APPENDIX: DEN LATINSKE TEKST}

[Guilelmi abbatis de Sancto Thoma in Paraclito epistula II 47]

[Ad dominum papam]

[Fragm. II 48b:] Ego sum ille Willelmus, qui primum beatae Genouefae canonicus secularis, deinde regularis, missus sum in Dacia, ubi abbas factus bis ad uos a domino Lundensi archiepiscopo Veneciis transmissus, Tusculanum uice alia, nepos abbatis sancti Germani H., quem uos plurimum dilexistis, qui uos et dominum Bernardum, Portuensem episcopum, in domo quadam beatae Genouefae suscepi ts iuxta Syluanectensem ciuitatem, cum obuiam iuissetis domino Maddeburgensi usque Compendium. Igitur quia me semper dilexistis gratia domini mei, praedicti abbatis Germani, uobis quaero consilium de quodam facto meo. Puer eram XV uel XVI annorum. [Fragm. II 47:] Erant duo, qui ad habenda beneficia mea uenire inhiabant. $\mathrm{Hi}$, quia me uide- 
bant habitum religionis appetere, in fraude et dolo circuierunt me, dicentes idem se uelle appetere. Iuratum est igitur a nobis super euangelium. Prouisum est monasterium, Pontiniacum scilicet, eet) statuta dies, qua stetimus ante abbatem ego et unus ex eis, se uero reddere noluit. Anno uno exacto iterum ad monasterium redire debuimus, sed hoc non fecimus, quia eorum nequitiam sum expertus. Interim in ecclesia nostra ordo sancti Victoris aduenit, quem ego suscipiens eius me institutionibus mancipaui et in eo L fere annos expleui. Modo quaero, mi domine, a uestra sanctitate, ut puero uestro significetis litteris uestris, in quo mihi sit ordine securius permanendum. Postulo etiam, mi domine pater, ut mihi litteris uestris, cum uoluero, ad ecclesiam meam Parisius confirmetur redeundi libertas, praecipue cum antequam exirem, et ordinem et sedem in choro et ubique mihi retinuerim in communi capitulo. Has etiam mihi rogo ita fieri consolatorias, ut omnes percipiant, qui eas uiderint et legerint, quam sincere me dilexeritis, et glorier in eis in tribulationum mearum angustiis.

Kommentarer: Se den danske oversættelse s. 12-14.

\section{KILDER OG LITTERATUR HÂNDSKRIFTER}

Det arnamagnæanske Institut, Københavns universitet:

AM. $10544^{\circ}$ (Vilhelmbreve, afskrevet for Arne Magnussen)

Det Kongelige Bibliotek:

Additamenta $1174^{\circ}$ (Vilhelmbreve, afskrevet for Vedel) [a]

E don. var. I $2^{\circ}$, Tom. 18 og I9, Thomas Bartholins Annales ecclesiae Danicae 1 10 I-1 300 (ca. 1690$)$

Gl. kgl. Saml. I I $52^{\circ}$ (Vilhelmbreve, afskrevet for Gram) [cl]

Gl. kgl. Saml. I I $62^{\circ}$ (Vilhelmbreve, afskrevet for Gram) [c2]

Ny kgl. Saml. 2 I 55 , b (1. del) $4^{\circ}$ (Vilhelmbreve, afskrevet af Vedel) [b]

Ny kgl. Saml. 2155 , b (2. del) $4^{\circ}$ (Vilhelmbreve, afskrevet for Bartholin (?)) [e]

Ny kgl. Saml. $3^{655} 8^{\circ}$ (Vilhelmbreve, afskrevet af magister Jorgen Claussen Warbjerg, ca. 1710) [d] 


\section{LITTERATUR}

Alenius r986: Marianne A., Hvem skrev dronning Ingeborgs breve?, Historisk Tidsskrift 86, 1986, s. 283-89; replik s. 291. [Imod Damsholt 1985]

Bartholin i689: Thomas B., Antiquitatum Danicarum de causis contemptae a Danis adhuc gentilibus mortis libri 3 , Kbh. 1689 .

Boserup 1982: Ivan B., [Anmeldelse af Christensen ${ }^{\circ}$ al. 1977], Historisk Tidsskrift 82, 1982 , S. $113-120$.

Boserup r 983 :-, En spogelseshistorie. Om den filologishe metode bag redaktionen af Diplomatarie-udgaven af abbed Wilhelms breve, Museum Tusculanum 52-55, 1983, s. 157-176.

Boserup ig84a: -, Om nogle fragmenter og nogle lakuner $i$ abbed Vilhelms brewsamlings archetypus, Man må studere ... festskrift til G. Torresin, Aarhus 1984, s. 45-62.

Boserup $1984 \mathrm{~b}:-$, Replik til C. A. Christensens antikritiske indlag om den nye udgave af abbed Wilhelms breve, Historisk Tidsskrift 84,1984, s. 86-87. [Imod Christensen 1983]

Boserup 1987: -, Hem var abbed Vilhelms onkel, Hugo af St.-Germain? (Vita $\$ \$ 1-5$ ), Museum Tusculanum 57, 1987, s, 6r-68.

Boserup I 988:--, Amor libere inter nos militans? Textual remarks on the Ars dictandi of Wilhelm of Ebelholt, A Literary Miscellany Presented to Eric Jacobsen. Publications of the Department of English, University of Copenhagen, Vol. 16, I988, s. 79-86.

Brial 1824: Michel Jean Joseph B., Saint-Guillaume, abbé de S.-Thomas du Paraclet, en Danemarck, Histoire littéraire de la France 16, Paris 1824 , s. 454-477.

Christensen \& Al. 1977: Epistola abbatis Willelmi de Paraclito ved C. A. Christensen, Herluf Nielsen, Lauritz Weibull, i: Diplomatarium Danicum, 1. rk. 3 . bd., s. $4^{10-576}$, Kbh. 1977. Hertil slutter sig oversattelsen i Danmarks Riges Breve.

Christensen 1983: C. A. C., Antikritiske bemarkninger til Itan Boserups anmeldelse af den nye udgave af abbed Withelms breve, Historisk Tidsskrift 83, 1983, s. 207-210. [Imod Boserup $1982]$

DAmborg 1867: Anders D., Abbed Vilhelms Leinet, Indbydelsesskrift ... Herlufsholm larde Skole ... 1867, Nestved 1867, s. 5-93.

Damsholt 1978: Nanna D., Abbed Vilhelm af Ebelholts brewsamling. Historisk Tidsskrift 78 , 1 978 , s. $\mathrm{t}-22$.

Damsholt 1985:-, Kvindebilledet i dansk hajmiddelalder, 339 s., Kbh. 1985 (Disputats).

Damsholt 1986: -, Siar fra Nanna Damsholt, Historisk Tidsskrift 86, 1986, s. 289-91; replik s. 291. [Imod Alenius 1986]

Gertz 1908: M. Cl. G. (ed.), Vitae sanctorum Danorum, Kbh. 1908-12.

Gram 1746: Joannis Meursii Historia Danica ... a Joanne Grammio scholiis perpetuis illustrata. Joannes Lamius recensuit, Florens 1746 .

Holberg 1732: Ludvig H., Damemarks Riges Historie, bd. 1, Kbh. 1732.

Kolderup-Rosenvinge i849: J. L. A. K., Den canoniske Rets Anzendelse i Danmark, Kirkehistoriske Samlinger 1, 1849, s. 1-54.

Migne 1855: J.-P. M. (ed.), Patrologia cursus completus, Series latina, ed. J.-P. Migne, bd. 209, Paris 1855, sp. 635-728. [Efter Suhm 1786]

Nielsen 1976: Herluf N., Vilhelm, Kulturhistorisk Leksikon for Nordisk Middelalder, bd. 20,1976 , sp. $69-71$. 
Norvin 1933: William N., Abbed Wilhelms Breve. Samlingens almindelige Karakter, Scandia 6, 1933, s. 153-1 72 .

Olrik 1894: Hans O., Danske Helgeners Leoned, Kbh. I894.

Pontoppidan 174r: Erik P., Annales ecclesiae Danicae diplomatici bd. 1, Kbh. 1741.

Sunм 1786: Peter Frederik S. (ed.), Wilhelmi Abbatis epistolae, Scriptores Rerum Danicarum, bd. 6 , I 786, s. I-79.

Walberg 1944a: Emmanuel W., Vem var abbot Wilhelm av Kbelholts „Dominus Petrus"?, [Svensk] Historisk Tidskrift 74, 1944, s. 29-37. [Imod Weibull 1943]

Walberg i944b:-, „Dominus Petrus". Kardinal eller påze eller bådadera?, [Svensk] Historisk Tidskrift 74, 1944, s. 355-368. [Imod Weibull 1944]

Walberg i947:-, Remarques sur une lettre de Saint-Guillaume, abbé de saint-Thomas-du-Paraclet ( Ebelholt), Classica et Mediaevalia 9, 1947, s. 231-245.

Weibult r 943: Lauritz W., Abbot Vilhelm av Lbelholts brev til dominus Petrus. Bakom diplomatiens kulisser pâ 1100-talet, Scandia 15, 1943, s. 32-40.

Weibull r. 1944:-, Påzen Alexander III $i$ Compiègne 1165 , Scandia 16 , I944, s. 85-89. [Imod Walberg 1944a] 